\title{
TP53 NP_000537.3:p.G245S
}

National Cancer Institute

\section{Source}

National Cancer Institute. TP53 NP 000537.3:p.G245S. NCI Thesaurus. Code C146896.

A change in the amino acid residue at position 245 in the cellular tumor antigen p53

protein where glycine has been replaced by serine. 